\title{
Reproductive efficiency of intensively managed thoroughbred mares in Newmarket
}

\author{
Lee H.A. Morris and W.R. Allen
}

Thoroughbred Breeders' Association Equine Fertility Unit, Mertoun Paddocks, UK

\begin{abstract}
Summary
The findings of a retrospective survey of 1393 Thoroughbred mares visiting 22 studfarms in the Newmarket region of the United Kingdom during the 1998 covering season were compared with those of a similar study undertaken 15 years earlier in 1983 . The effects of mare age and status, the stallion, the month of mating, the application of uterine treatments and other parameters on the rates of singleton and twin conception and subsequent pregnancy losses were analysed. Mare age and status significantly affected the per cycle pregnancy rate and the incidence of pregnancy loss. Overall, the mean number of matings per oestrus was 1.12 and the mean number of times a mare was mated until diagnosed pregnant at 15 days after ovulation was 1.88. An overall mean per cycle pregnancy rate of $59.9 \%$ at 15 days after ovulation resulted in $94.8 \%$ of the mated mares being pregnant at least once at 15 days after ovulation. This high initial pregnancy rate fell to $89.7 \%$ by day 35 and $87.5 \%$ by the time of the October pregnancy test; $82.7 \%$ of the mares surveyed gave birth to a live foal at term, which compares favourably with the proportion of mares foaling in 1983 (77\%). However, despite improvements in the foaling rates over the last 15 years, the overall rate of pregnancy failure remains high and represents a major loss to the Thoroughbred breeding industry.
\end{abstract}

Keywords: $\quad$ equine pregnancy, pregnancy loss, foaling rate, twins

\section{Fruchtbarkeitsleistung bei intensiv betreuten Vollblutstuten in Newmarket}

Die Ergebnisse einer retrospektiven Auswertung von Daten über 1393 Vollblutstuten aus 22 Gestüten der Region Neumarket (UK) während der Decksaison 1998 werden mit den Ergebnissen einer ähnlichen Studie, durchgeführt 15 Jahre zuvor im Jahr 1983, verglichen.

Die Einflüsse von Lebensalter und Fruchtbarkeitsstatus der Stuten, des Hengstes, Bedeckungsmonat, uterinen Behandlungen und weiterer Parameter auf Einlings- und Zwillingsrate und folgender Trächtigkeitsverluste wurden analysiert. Das Alter und der Fruchtbarkeitsstatus der Stuten beeinflussten signifikant die Konzeptionsrate pro Zyklus und das Auftreten von Fruchtverlusten. Insgesamt betrug die mittlere Zahl der Bedeckungen je Rosse 1,12. Bezogen auf die am 15. Tag p.c. festgestellte Gravidität betrug die mittlere Bedeckungszahl 1,88. Eine am 15. Tag post ovulationem festgestellte mittlere Trächtigkeitsrate pro Zyklus von 59,9\% ergab eine Gesamtrate von 94,8\% tragender Stuten, die am Tag 15 als tragend diagnostiziert wurden. Diese hohe initiale Trächtigkeitsrate sank auf 89,7\% am Tag 35 und auf 87,5 bei den Nachuntersuchungen im Herbst. 82,7\% der in die Studie einbezogenen Stuten brachten ein lebendes Fohlen zum regulären Geburtstermin, womit ein vergleichbares Ergebnis von 1983 mit 77\% erzielt wurde. Trotz der Verbesserung der Abfohlraten innerhalb der letzten 15 Jahre bleibt der Anteil der Fruchtverluste hoch und repräsentiert einen der Hauptverlustquellen der kommerziellen Vollblutzucht.

Schlüsselwörter: Konzeptionsrate Pferd, Fruchtverluste, Abfohlrate, Zwillinge

\section{Introduction}

The Thoroughbred horse has often been accused of poor reproductive efficiency compared with studies examining pasture mated mares, which have recorded pregnancy rates greater than $85 \%$ after a stallion was placed with them for only two oestrous cycles (Bristol, 1982; 1987). On the other hand, retrospective surveys of the reproductive parameters of Thoroughbred, Standardbred and Quarterhorse mares have revealed per cycle pregnancy rates of only 43-56\% (Sullivan et al, 1975; Ginther, 1982, 1983; Woods et al, 1987; Brück et al, 1993), cumulative end-of-season pregnancy rates of 70-80\% (Laing and Leech, 1975; von Lepel, 1975; Sullivan et al, 1975; Brück et al, 1993), and foaling rates as low as $50-70 \%$ (Laing and Leech, 1975; Osborne, 1975; Merkt et al, 1979; Jeffcott et al, 1982; Brück et al, 1993; Morley and Townsend, 1997).

In a detailed survey of the breeding records of 1367 Thoroughbred mares that visited studfarms in the Newmarket area of England during the 1982 covering season, Sanderson and Allen (1987) recorded an overall pregnancy rate per mated oestrous cycle of $52.4 \%$, an end-of-season pregnancy rate of $88.7 \%$ recorded between 60 and 90 days after the last mating, and a live foal birthrate the following year of $74.7 \%$.

The age of the mare (Held and Rohrbach, 1991; Hutton and Meacham, 1968; Jeffcott et al, 1982; Laing and Leech, 1975; Sanderson and Allen, 1987; Waelchi, 1990; Ricketts and Alonso, 1991) and her status as a maiden, barren or lactating individual (Sanderson and Allen, 1987; Woods et al, 1987; Ricketts and Alonso, 1991) have been shown to influence her chances of conceiving and producing a live foal. These various mare factors, together with the management of the stallion (Sullivan and Pickett, 1975), contribute greatly to the overall reproductive efficiency of any group of horses. In the present study we examined the effects of such parameters as mare age and status, stallion, month of mating and the application of various uterine treatments on the rates of singleton and twin conception, and upon the incidence and timing of pregnancy losses, in a large group of intensively managed Thoroughbred mares. 


\section{Materials and methods}

A retrospective survey of the mating, veterinary examination and subsequent foaling records of 1393 Thoroughbred mares that visited one of 83 stallions standing on 22 studfarms in Newmarket and other parts of East Anglia during the 1998 covering season was carried out. Individual mares were excluded from the analysis if specific features of their breeding records were incomplete for a particular calculation and only those stallions that had covered more than 10 mares were included in the analyses of stallion performance. Statistical analyses were performed on the subpopulations of mares with complete information about their age, foaling status, application of uterine treatments, number of matings and pregnancy tests from mating until foaling. The mares were grouped according to age (3$8 y, 9-13 y, 14-18 y,>18 y$ ) or reproductive status (maiden, barren, foaling, aborted, rested) at the beginning of the 1998 covering season.

The records associated with a total of 2173 periods of oestrus exhibited by the 1393 mares were analysed. Those oestrous cycles $(n=40)$ in which mating did not occur were excluded from the analysis of reproductive parameters. Information pertaining to the dates, distribution of ovulations between the ovaries and the number of ovulations followed by ultrasonographic diagnosis of pregnancy around 15 days later, was complete for 1928 oestrous cycles. The population distributions of the mares on the bases of age and reproductive status are shown in Table 1. Of the 83 stallions that mated this population

Tab. 1: The effects of mare. a) age and (left table), b) reproductive status on measures of reproductive efficiency in the Thoroughbred (right table).

Einfluss von Seiten der Stute. a) Alter (linke Tabelle), b) Fruchtbarkeitsstatus auf Daten der Fruchtbarkeitsleistung in der Vollblutzucht (rechte Tabelle)

\begin{tabular}{|l|c|c|c|c|c|}
\hline Mare Age Group & $3 \tilde{n} 8$ yo & $\begin{array}{c}9 \tilde{n} 13 \\
\text { yo }\end{array}$ & $\begin{array}{c}14 \tilde{n} 18 \\
\text { yo }\end{array}$ & $\begin{array}{c}<18 \\
\text { yo }\end{array}$ & Total \\
\hline No. mares & 612 & 340 & 160 & 32 & 1144 \\
\hline No. oestrous cycles & 959 & 567 & 315 & 70 & 1911 \\
\hline \multicolumn{1}{|l|}{ Management of oestrus } & 1.11 & 1.14 & 1.14 & 1.07 & 1.12 \\
\hline $\begin{array}{l}\text { No. matings / } \\
\text { oestrus }\end{array}$ & $1.78^{a}$ & $1.86^{a}$ & $2.22^{b}$ & 2.14 & 1.88 \\
\hline $\begin{array}{l}\text { No. matings per } \\
\text { day 15 pregnancy }\end{array}$ & $9.38^{a}$ & $10.22^{a}$ & $21.9^{b}$ & $24.29^{b}$ & 12.24 \\
\hline $\begin{array}{l}\text { \% oestrous cycles } \\
\text { given uterine } \\
\text { treatment }\end{array}$ & & & & \\
\hline
\end{tabular}

\section{Pregnancy results}

\begin{tabular}{|c|c|c|c|c|c|}
\hline $\begin{array}{l}\text { Day } 15 \\
\text { pregnancies / } \\
\text { oestrus }\end{array}$ & $62.7^{a}$ & $61.2^{\mathrm{a}}$ & $51.4^{b}$ & 50.0 & 59.92 \\
\hline $\begin{array}{l}\text { Day } 35 \\
\text { pregnancies / } \\
\text { oestrus }\end{array}$ & $59.8^{a}$ & $52.7^{b}$ & $40.3^{c}$ & $38.6^{b, c}$ & 53.69 \\
\hline $\begin{array}{l}\% \text { mares pregnant } \\
\text { in October }\end{array}$ & $90.4^{a}$ & $87.7^{a}$ & $76.9^{b}$ & 84.4 & 87.50 \\
\hline $\begin{array}{l}\% \text { pregnancies lost } \\
\text { day } 15-35\end{array}$ & $4.7^{a}$ & $13.8^{b}$ & $21.6^{b}$ & 22.9 & 10.39 \\
\hline $\begin{array}{l}\text { \% pregnancies lost } \\
\text { day } 35 \text { ñ October }\end{array}$ & $3.3^{a}$ & $0.3^{b}$ & 2.5 & 0 & 2.18 \\
\hline $\begin{array}{l}\text { \% pregnancies lost } \\
\text { October ñ foaling }\end{array}$ & 3.8 & 6.6 & 3.7 & 8.6 & 4.80 \\
\hline $\begin{array}{l}\text { Overall \% } \\
\text { pregnancies lost }\end{array}$ & $11.8^{a}$ & $20.8^{b}$ & $27.8^{b}$ & $31.4^{\mathrm{b}}$ & 17.38 \\
\hline $\begin{array}{l}\% \text { mares produced } \\
\text { a live foal. }\end{array}$ & $86.6^{a}$ & 80.9 & $73.1^{b}$ & 75.0 & 82.69 \\
\hline
\end{tabular}

\begin{tabular}{|l|c|c|c|c|c|}
\hline Mare Status & Maiden & Barren & Foaling & Aborted & Rested \\
\hline No. mares & 186 & 170 & 749 & 22 & 17 \\
\hline No. oestrous cycles & 304 & 309 & 1220 & 37 & 41 \\
\hline
\end{tabular}

Management of oestrus

\begin{tabular}{|l|c|c|c|c|c|}
\hline $\begin{array}{l}\text { No. matings / } \\
\text { oestrus }\end{array}$ & 1.12 & 1.12 & 1.13 & 1.16 & 1.02 \\
\hline $\begin{array}{l}\text { No. matings per } \\
\text { day 15 pregnancy }\end{array}$ & 1.85 & 2.03 & 1.84 & 1.79 & 2.8 \\
\hline $\begin{array}{l}\text { \% oestrous cycles } \\
\text { given uterine } \\
\text { treatment }\end{array}$ & $3.9^{\mathrm{a}}$ & $14.9^{\mathrm{b}}$ & $13.8^{\mathrm{b}}$ & $18.9^{\mathrm{b}}$ & 2.4 \\
\hline
\end{tabular}

\begin{tabular}{|l|c|c|c|c|c|}
\hline \multicolumn{2}{|l|}{ Pregnancy results } \\
\hline $\begin{array}{l}\text { Day 15 } \\
\text { pregnancies / } \\
\text { oestrus }\end{array}$ & $61.2^{\circ}$ & 55.3 & 61.4 a & 64.9 & 36.6 b \\
\hline $\begin{array}{l}\text { Day 35 } \\
\text { pregnancies / } \\
\text { oestrus }\end{array}$ & 58.9 a & 50.8 & 53.8 & 54.1 & $34.2^{b}$ \\
\hline $\begin{array}{l}\text { \% mares pregnant } \\
\text { in October }\end{array}$ & 91.9 & 92.4 & 85.6 & 81.8 & 82.4 \\
\hline $\begin{array}{l}\text { \% pregnancies lost } \\
\text { day 15ñ35 }\end{array}$ & 3.8 a & 8.2 & 12.4 b & 16.7 & 6.7 \\
\hline $\begin{array}{l}\text { \% pregnancies lost } \\
\text { day 35ñ October }\end{array}$ & 4.3 & 0 & 2.0 & 8.3 & 0 \\
\hline $\begin{array}{l}\text { \% pregnancies lost } \\
\text { October ñ foaling }\end{array}$ & 6.5 & 3.5 & 4.4 & 8.3 & 13.3 \\
\hline $\begin{array}{l}\text { Overall \% } \\
\text { pregnancies lost }\end{array}$ & 14.5 & 11.7 a & 18.8 & 33.3 b & 20.0 \\
\hline $\begin{array}{l}\text { \% mares produced } \\
\text { a live foal. }\end{array}$ & 85.5 & 88.8 & 81.2 & 72.7 & 70.6 \\
\hline
\end{tabular}

$a, b$ Values in the same row with different superscripts differ significantly (Total column excluded), $\chi^{2}$ test. Table a) Bonferroni $p<0.008$, table b) Bonferroni $p<0.005$ 
of mares, 41 covered $>10$ mares $(n=1134$ mares, 1822 oestrous cycles).

\section{Results}

Management of the oestrous cycle

Of 2133 periods of oestrus in which mating occurred, 1540 $(72.2 \%)$ arose spontaneously and included 210 (13.6\%) post partum oestrous periods within 15 days after foaling (the "foal heat"). The remaining 593 oestrous periods $(27.8 \%)$ were induced by the administration of one or more exogenous hormones which included

i) a single intramuscular (i.m.) injection of the prostaglandin $\mathrm{F}_{2 \alpha}$ analogue, cloprostenol (Estrumate; Schering Plough, Uxbridge, UK);

ii) withdrawal, after 10 days oral administration, of the synthetic progestagen, altrenogest (Regumate; Intervet, Milton Keynes, $\mathrm{UK}$;

iii) subcutaneous implantation of a low dose, slow release formulation of a GnRH analogue (Zoladex; Zeneca Pharmaceutical Co, Cheshire, UK), or

iv) multiple 2 - 3 times daily i.m. injections of small doses of an aqueous preparation of another $\mathrm{GnRH}$ analogue (Receptal; Intervet) given to mares in transitional anoestrus. When a preovulatory follicle was detected in the mare's ovaries, either by transrectal palpation or ultrasound scanning; ovulation was allowed to occur spontaneously in $49 \%$ of the oestrous cycles. In a further $49 \%$ of cycles an intravenous (i.v.) injection of human Chorionic Gonadotrophin (Chorulon; Intervet) was administered to hasten ovulation. In $1 \%$ of cycles an i.v. injection of Receptal was given to hasten ovulation and in a further $1 \%$ of cycles Estrumate was given for this purpose.

Overall, 2148 matings occurred in 1911 periods of oestrus exhibited by 1144 mares and resulted in a total of 1145 pregnancies at day 15 after ovulation (Table 1a). These results gave a mean number of matings per period of oestrus of 1.12 , and the mean number of times a mare was mated until diagnosed pregnant at around day 15 after ovulation was 1.88 . Neither mare age nor mare status influenced the number of matings per oestrus but mare age did influence the number of matings required for each pregnancy diagnosed 15 days after ovulation ( $p<0.001$; Table 1). Overall, there was little variation in the estimated mean ( \pm s.d.) number of days between mating and ovulation $(1.16 \pm 0.6)$, and variations in the length of the interval did not influence pregnancy rates.

Uterine treatments were given in $12.24 \%$ oestrous cycles and they included saline lavage of the uterus, intrauterine infusion of antibiotics and parenteral administration of oxytocin to aid expulsion of accumulated uterine fluid. Fewer maiden mares $(p<0.0001)$ received uterine treatments than barren or foaling mares, or mares that had aborted (Table 1). Uterine treatment was applied in significantly more oestrous cycles in 14-18yo mares $(p<0.0001)$ and $>18$ yo mares $(p<0.0001)$ than in cycles exhibited by the younger age groups (Table 1). The period of oestrus after foaling significantly influenced the application of uterine therapy ( $p=0.004$; Table 2$)$, such that more mares were treated if still being covered at around 61 days after foaling, than those covered in the first two oestrous periods after foaling.

\section{Pregnancy rates}

The mean \pm s.d. first ultrasonographic diagnosis of pregnancy was performed at $15.1 \pm 3$ days after ovulation. For 1911 oestrous cycles that were accompanied by complete information about matings, uterine treatments and pregnancy diagnoses, an overall per cycle pregnancy rate of $59.92 \%$ was recorded at day 15 after ovulation, which fell to $53.69 \%$ by day 35 . The lowest per cycle pregnancy rates at around day 35 occurred in the 14-18yo, and the >18 yo mares, and in the rested mares. There was no overall effect of the month in which mating occurred on the per cycle pregnancy rates (Table 3), or on the proportions of mares that received uterine treatment. However, the overall per cycle pregnancy rate from matings in May $(62.7 \%)$ was higher $(p=0.027)$ than that for June and July combined (52.6\%). There was no effect of the type of oestrus, whether spontaneous or induced by treatment with either Regumate or Estrumate, on per cycle pregnancy rates at around days 15 and 35 after ovulation.

Complete information, from mating to foaling, was available for 1144 mares. By the end of the covering season, only 60

Tab. 2: The incidence of the use of uterine therapy and pregnancy rates in foaling mares.

Häufigkeit uteriner Therapie und Trächtigkeitsraten bei Fohlenstuten

\begin{tabular}{|c|c|c|c|c|c|c|c|c|}
\hline \multirow{2}{*}{ Type of oestrus } & \multirow{2}{*}{$\begin{array}{l}\text { No. } \\
\text { mares }\end{array}$} & \multirow{2}{*}{$\begin{array}{l}\text { No. } \\
\text { oestrous } \\
\text { cycles }\end{array}$} & \multirow{2}{*}{$\begin{array}{l}\text { Mean } \pm \text { s.d. } \\
\text { interval } \\
\text { foaling to } \\
\text { ovulation } \\
\text { (days) }\end{array}$} & \multirow{2}{*}{$\begin{array}{c}\text { Uterine } \\
\text { treatment (\% } \\
\text { mares) }\end{array}$} & \multicolumn{4}{|c|}{ Pregnancy rate at } \\
\hline & & & & & $\begin{array}{c}\text { day } 15 \\
\text { (\% cycles) }\end{array}$ & $\begin{array}{l}\text { day } 35 \\
\text { (\% cycles) }\end{array}$ & $\begin{array}{l}\text { October } \\
\text { (\% mares) }\end{array}$ & $\underset{\text { mares) }}{\text { Live foal }}(\%$ \\
\hline Foal heat & 210 & 210 & $11 \pm 2$ & $9.5^{\mathrm{a}}$ & $57.6^{a, b}$ & $48.1^{a}$ & $45.7^{a}$ & $45.2^{a}$ \\
\hline $\begin{array}{l}\text { Second oestrus } \\
\text { after foaling }\end{array}$ & 560 & 560 & $34 \pm 12$ & $11.6^{a}$ & 65.9 a & $58.8^{\mathrm{b}}$ & $55.9^{b}$ & $52.1^{a}$ \\
\hline $\begin{array}{l}\text { Subsequent } \\
\text { periods of oestrus }\end{array}$ & 317 & 491 & $61 \pm 25$ & $18.3^{b}$ & $58.5^{b}$ & $50.7^{a}$ & $73.5^{c}$ & $67.5^{b}$ \\
\hline
\end{tabular}

a,b Values in the same row with different superscripts differ significantly (Total column excluded), $\chi^{2}$ test, Bonferroni $p<0.0167$ 
mares (5.2\%) had never been diagnosed pregnant and 1084 (94.8\%) mares had been diagnosed pregnant at least once at around 15 days after ovulation; 12 of these mares lost 2 or more pregnancies during the season. By around day 35 after ovulation, $1026(89.7 \%)$ mares were still pregnant and 1001 $(87.5 \%)$ remained in foal at $5-8$ months of gestation at the time of the October pregnancy test. Ultimately, $82.7 \%$ of the 1144 mated mares produced a live foal in 1999. Thus, a significantly $(p=0.005$ ) higher proportion of live foals were born from the mares in this Newmarket population than from the whole of the Thoroughbred mare population of Britain and Ireland in the same year (12,704 foals born from 16,039 mares; $79.21 \%$ ) as recorded in Weatherby's Annual Returns (S.W. Ricketts, pers comm.).

In these 1144 mares for which complete details of pregnancy were available (Table 1), 199 of the 1145 (17.3\%) pregnancies diagnosed at around day 15 after ovulation were subsequently lost. The majority of the pregnancy losses $(119$ / 199,59.7\%) occurred between days 15 and 35 of gestation. Thereafter, a further 80 pregnancies were lost $(80$ / 1145 , $7 \%$ ) which is significantly less than the pregnancy loss rate $(12.4 \%, p=0.0003)$ observed for the same stage of gestation in $1982 / 83$. Both the age $(p<0.001)$ and reproductive status $(p=0.035)$ of the mare had significant effects on the overall proportions of pregnancies that were lost (Table 1). Mares in the 3-8ys age group lost significantly fewer pregnancies between days 15 and 35 after ovulation ( $p<$ 0.001 ) than the older mares, but curiously, these younger mares subsequently lost more pregnancies between day 35 and the October pregnancy test than did their 9-13 ys counterparts $(p=0.002)$. Maiden mares lost significantly fewer pregnancies between days 15 and 35 after ovulation than foaling mares $(p=0.0006)$, although the pregnancy loss rates between day 35 and the October pregnancy test were similar among the other groups of mares of differing reproductive status. The pregnancy loss rates between the October pregnancy test and foaling were also similar across all the age and mare status groups.

There was a tendency for higher day 15 pregnancy rates in foaling mares that were mated for the first time in an oestrus that occurred $>15$ days after foaling, compared with those mated during the foal heat ( $p=0.03$; Table 2). Furthermore, significantly more pregnancies were lost between days 15 and 35 after ovulation in the foaling mares that were mated during the foal heat than in those mated for the first time during the oestrus which occurred at a mean \pm s.d. of $34 \pm 12$ days post partum. There were also significant differences in the October pregnancy rates between the foaling mares that had been mated during their foal heat, and those mated for the first time $>15$ days after foaling, or re-mated in subsequent oestrous periods (Table 2). Ultimately, however, there were no significant differences in foaling rates between the mares mated during their foal heat and those mated in the first oestrus $>15$ days after foaling ( $p=0.087$; Table 2$)$. The highest proportion of live foals was produced from mares mated during subsequent oestrous periods, which occurred at around $61 \pm 25$ days post partum (Table 2).
Management of twins

Single ovulations were recorded by the attending veterinary clinician in $85.7 \%$ of oestrous cycles, bilateral double ovulations in $10 \%$ of cycles and unilateral double ovulations in $4.3 \%$ of cycles. In the previous survey in 1982 and 1983, twin ovulations had been detected in $14 \%$ of the oestrous cycles $(n=5287)$. Despite a similar incidence of twin ovulations observed in the two studies, a significant increase had occurred in the overall per cycle twin pregnancy rate, from $2.1 \%(n=4653)$ in $1982 / 83$ to $6.8 \%$ in $1998(p<0.001)$. The majority of twin pregnancies in the present survey (61.4\%) had resulted from "detected single" ovulations, while $31.8 \%$ resulted from "detected bilateral double" ovulations and $6.8 \%$ from "detected unilateral double" ovulations. However, the overall day 15 pregnancy rate per cycle was similar in mares in which twin ovulations (65.7\%) or a single ovulation (60.2\%) had been detected previously.

Tab. 3: Factors influencing the incidence of twin ovulations and twin pregnancies in mares.

Einflussfaktoren auf Doppelovulations-Vorkommen und Zwillingsträchtigkeiten bei Stuten

\begin{tabular}{|c|c|c|c|c|}
\hline $\begin{array}{l}\text { Mare } \\
\text { age } \\
\text { (years) }\end{array}$ & $\begin{array}{c}\text { No. } \\
\text { mated } \\
\text { oestrous } \\
\text { periods }\end{array}$ & $\begin{array}{c}\text { Twin } \\
\text { ovulations } \\
\text { (\% mated } \\
\text { oestrous } \\
\text { periods) }\end{array}$ & $\begin{array}{l}\text { Singleton } \\
\text { pregnancies } \\
\text { (\% mated } \\
\text { oestrous } \\
\text { periods) }\end{array}$ & $\begin{array}{c}\text { Twin } \\
\text { pregnancies } \\
\text { (\% mated } \\
\text { oestrous } \\
\text { periods) }\end{array}$ \\
\hline $3 \tilde{8} 8$ & 989 & $13.3^{\circ}$ & $55.5^{a}$ & 7.0 \\
\hline $9 \tilde{13}$ & 562 & 13.0 & 57.5 & 6.8 \\
\hline $14 \tilde{1} 18$ & 307 & $19.5^{b}$ & $43.3^{b}$ & 7.5 \\
\hline$>18$ & 70 & 24.3 & 44.3 & 2.9 \\
\hline \multicolumn{5}{|c|}{ Mare status } \\
\hline Maiden & 301 & 14.6 & $55.2^{\mathrm{a}, \mathrm{c}}$ & $7.0^{\circ}$ \\
\hline Barren & 306 & $22.9^{a}$ & $46.1^{a, b}$ & $8.2^{\mathrm{a}}$ \\
\hline Foaling & 1243 & $12.0^{\mathrm{b}}$ & $56.6^{c}$ & $5.7^{a}$ \\
\hline Aborted & 38 & 26.3 & 39.5 & $23.7^{b}$ \\
\hline Rested & 40 & 20.0 & $25.0^{\mathrm{b}}$ & 15.0 \\
\hline \multicolumn{5}{|c|}{ Month of ovulation } \\
\hline February & 213 & $14.6^{\circ}$ & 51.2 & $11.3^{a}$ \\
\hline March & 519 & $13.5^{a}$ & 53.6 & 7. \\
\hline April & 518 & $12.7^{\circ}$ & 53.7 & 6.2 \\
\hline May & 503 & $16.7^{\circ}$ & 57.7 & $5.0^{b}$ \\
\hline June & 162 & $14.2^{\circ}$ & 46.3 & 6.8 \\
\hline July & 13 & $58.3^{b}$ & 46.2 & 0 \\
\hline
\end{tabular}

$a, b$ Values within the same column with different superscripts differ significantly, $\chi^{2}$ test, Bonferroni $p<0.008$ 
There was an overall effect of both mare age $(p<0.0001)$ and mare status $(p<0.005)$ on the twin ovulation rate and the singleton pregnancy rate in each oestrous cycle (Table 3 ). However, mare age had no effect on the per cycle twin pregnancy rate, whereas mare status did $(p<0.0001)$. Foaling mares showed significantly fewer twin ovulations than barren mares ( $p$ $<0.0001$ ), and the highest twin pregnancy rate was recorded in mares that had aborted in the previous year (Table 3). In addition, there was an overall effect of month in which ovulation occurred, both on twin ovulation rate $(p<0.001)$ and the per cycle twin pregnancy rate $(p=0.019)$.

A total of 154 twin pregnancies were recorded throughout the season, of which 132 were treated by manual crushing of one conceptus per rectum between days 13 and 18 after ovulation, and another 7 mares had a conceptus crushed between days 19 and 30 . Of 125 manual crushing attempts for which complete follow-up records were available, 114 (92.1\%) were reduced successfully to singletons, including 3 mares that required two crushing attempts (Table 4). The distribution of the twin conceptuses in the uterus was recorded in 136 cases and there was an apparent 10\% increase in the success rate of manual crushing when the two conceptuses were distributed bilaterally (Table 4). Only one of the mares in which twins were treated successfully by manual crushing of one conceptus, lost her remaining singleton pregnancy after day 35 of gestation.

\section{Discussion}

The findings in this survey reinforce the concept that mare age and reproductive status exert major influences on pregnancy and foaling rates in the Thoroughbred; these two parameters also had the most prominent effect on reproductive performance in the survey carried out 15 years previously by Sanderson and Allen (1987). The 60\% per cycle pregnancy rate at around day 15 after ovulation reflected earlier ultrasonographic detection of pregnancy in the present study compared with 1982/1983 when the mares were examined ultrasonographically between days 16 and 42 after mating only if they had not returned to oestrus. Indeed, the $54 \%$ per cycle pregnancy rate at around day 35 in 1998 more closely resembles the 53\% per cycle pregnancy rate reported in the 1982/83 study.

The ability to diagnose the presence or the absence of a conceptus in the uterus ultrasonographically as early as day 12 after ovulation now enables the veterinary surgeon to monitor accurately the incidence of early pregnancy loss in the mare by means of repeated follow-up scanning examinations. Consequently, earlier pregnancy diagnosis may have contributed to the "apparent increase" in overall pregnancy loss rates between the first pregnancy diagnosis and foaling which rose from $12 \%$ in $1982 / 83$ to $17 \%$ in 1998 . However, if fertilization rates are indeed as high as the $80-90 \%$ figure noted by Ball et al., (1986) in the aged and young experimental mares, the per cycle pregnancy rates recorded in 1998 could possibly reflect an early embryonic loss rate prior to day 15 as high as $20-30 \%$. Thereafter, the majority of the recorded pregnancy losses in mares in the present study occurred between days 15 and 35 after ovulation, and hence during the period of maternal recognition of pregnancy and early fetal development, when such losses are likely to be associated with deficiencies in the uterine environment (Wathes, 1992).

Despite the high pregnancy loss rates in early gestation, the overall proportion of mares that produced a live foal increased from $74.7 \%$ to $82.8 \%$, during the 15 -year interval between the two surveys. This was parallelled by a similar increase in foaling rates in registered Thoroughbred mares as recorded by Weatherbys General Stud Book, from $71.4 \%$ in 1982 to $79.2 \%$ in 1998 (Figure 1; Ricketts and Barrelet, 2001).

The increase in foaling rates may also reflect a beneficial effect of the improvements in the management of oestrus, the timing of a single mating during oestrus and the implementation of uterine therapy when deemed necessary. This is supported by the finding of a lack of significant differences in the per cycle pregnancy rates of mares that received uterine therapy and those that did not. It is reasonable to assume that some of the older and subfertile mares susceptible to the accumulation of intrauterine fluid and/or endometritis would have had lower per cycle pregnancy rates had they not been treated (Pycock and Newcombe, 1996).

The age distribution of the mares included in the present survey was essentially similar to those of the populations surveyed in 1982 and 1983 (Sanderson and Allen, 1987). However, there were differences in the reproductive status of the mares in that the proportion of maiden mares had increased from $12 \%$ in 1983 to $16 \%$ in 1998 and, conversely, the proportion of barren mares had fallen from $24 \%$ to $15 \%$, reflecting better management and increased culling of barren mares in the 15 year interval between the two surveys. Indeed, in 1998, there were no longer any differences in the per cycle pregnancy rates for barren mares than for foaling or maiden mares. The observation that mares which were not covered during the 1997 stud season had significantly lower per cycle pregnancy rates than their counterparts in 1998 suggests that "resting" mares voluntarily for a year may not be advantageous to their fertility.

The mares in the 3-8y.o. and 9-13y.o. age groups had similarly high per cycle day 15 pregnancy rates of, respectively, 63\% and $61 \%$. However, the rate dropped quite sharply to $51 \%$ in the 14-18y.o. mares, which meant, in turn, that these older animals required significantly more matings per conception (2.2) than the younger mares (1.8). Concomitantly, the proportion of oestrous cycles in which uterine therapy was used was lowest in the maiden mares $(4 \%)$ and mares aged $\leq 14$ years $(9-10 \%)$, but the level rose steeply to $>20 \%$ in mares aged $>14$ years. It was not unexpected that, with increasing age and, therefore, progressive degenerative changes in the endometrium and susceptibility to infection, an increase would occur in the need for uterine treatment. Moreover, the younger, and presumably more fertile, maiden mares were treated significantly less frequently than older barren and foaling mares. Thus, regardless of the administration of uterine therapy, the effects of mare age and reproductive status on the per cycle pregnancy rates prevailed.

The incidence of pregnancy loss was lowest in the young mares aged 3-8 years and, surprisingly, the overall rate nearly doubled in the 9-13 year olds, perhaps as a result of the onset of age 
related degenerative changes in the endometrium reducing its nutritive capacity for the developing conceptus (Bracher et al, 1996). The absence of any differences in the incidence of pregnancy loss between maiden mares and barren or foaling mares supports the conclusion of Ricketts and Alonso (1991) that the age, more than the parity, of a mare influences the condition of her endometrium. Adams et al (1987) also observed an increase in pregnancy loss rate with increasing mare age which they related to an increasing incidence of endometrial cysts. By comparison, Sullivan et al, (1975) reported higher pregnancy losses in barren mares (16\%) than in maiden or foaling mares (8-9\%). However, the significant advances which have occurred during the past 25 years in the detection and treatment of uterine problems in mares may have gradually eliminated the differences in pregnancy loss rates between the groups of mares of differing reproductive status.

The sharp increase in pregnancy loss rates recorded in the 913y.o. mares in 1998 (20.8\%) differed markedly from the loss rate of only $10.2 \%$ in the same age group noted in the 1982/ 1983 survey. Again, this may have been a reflection of the earlier ultrasonographic detection of pregnancy and, subsequently, pregnancy losses when carrying out repeat ultrasound examinations between days 15 and 35 after ovulation. Thus, the initial $61 \%$ per cycle pregnancy rate recorded at around day 15 in the $9-13$ y.o. mares in 1998 fell to $53 \%$ by day 35 and thereby became more comparable with the per cycle pregnancy rate of $55 \%$ recorded in $1982 / 1983$. Similarly, the initial $61 \%$ per cycle pregnancy rates diagnosed in foaling mares at day 15 compared favourably with the 1982 per cycle pregnancy rate of $55.6 \%$ when examinations were performed only between days 16 and 42 . Once again, the earlier and more accurate pregnancy diagnosis may account for the apparent increase in pregnancy losses in foaling mares since 1982 , from $12.5 \%$ to $18.8 \%$ between the first pregnancy diagnosis and foaling. However, only 12 mares lost more than one pregnancy after day 15 in the 1998 season, of which 10 were $>9$ years of age and 10 were foaling mares, thereby suggesting age-related endometrosis and/or post-foaling endometritis as the likely causes of the losses in these two groups. Pregnancy rates remained relatively steady during the season until June and July when they dropped steeply. This no doubt reflects the high fertility of the early cycling maiden mares and early foaling mares that had conceived without difficulty in the previous year. Mares mated later in the covering season most likely reflect the population of sub-fertile, problem mares that had either taken longer to conceive in the previous season and, consequently, had foaled later in 1998, or had difficulty conceiving in 1998 and required repeated matings in successive oestrous cycles. A similar decline in per cycle pregnancy rates at the end of the season was observed in the 1982/83 survey. The overall per cycle pregnancy rate in the mares in which twin ovulations were detected by the attending veterinary surgeon was similar to that observed in mares in which a single ovulation was detected. However, not all twin ovulations were detected or recorded since as many as $61 \%$ of all the twin pregnancies diagnosed were found in mares in which only a single ovulation had been recorded. This discrepancy is most likely to have resulted from either a failure to record the second ovulation, or the occurrence of a second undetected early dioestrous ovulation occurring 2-6 days after rupture of the primary follicle when the mare's ovaries were no longer being monitored ultrasonographically. The appreciably higher twin conception rate that resulted from bilateral twin ovulations (32\%), compared with unilateral twin ovulations (7\%), is consistent with the suggestion by Ginther (1989) that multiple ovulations from the same ovary in the mare may distort the orientation of the infundibulum of the oviduct in relation to the ovulation fossa, so leading to loss of ovulated oocytes into the abdomen. Alternatively, the lower incidence of unilateral twin ovulations may reflect the increased risk of error in the detection of two follicles in the same ovary, compared with the increased ease of detection of two follicles in separate ovaries.

The incidence of twin ovulations detected in 1998 was similar to that observed in the 1982/83 survey despite the increased use of the ultrasound scanner to monitor ovulation since that time. The highest twin ovulation rate was recorded in barren mares and the lowest in foaling mares in both surveys. The earlier study failed to detect any association between the age of the mare and the incidence of twin ovulations whereas, in the 1998 season, the overall twin ovulation rate of 13\% detected in mares $<14$ years of age jumped significantly to $>19 \%$ in the mares aged $>14$ years. A similar increase in ovulation rates with increasing age has been reported in sheep (Duane and Buckrell, 1997). Indeed, this increase in twin ovulations with increasing age in the mare may partially compensate for a progressive reduction in per cycle pregnancy rate in the older mares. Twin ovulation rates were significantly higher in barren than foaling mares in both the 1982/83 and 1998 surveys, thereby suggesting strongly that the occurrence of multiple ovulations may also be influenced by lactation and nutritional status, as has been observed to be the case in sheep (Downing and Scarramuzzi, 1991; Fogarty, et al, 1991).

The overall twin pregnancy rate of $7 \%$ recorded in the 1998 covering season was over double the equivalent figure of $2.4 \%$ noted in 1982/3. This sharp increase during the 15 year period between the two surveys is likely to have many causes. First, a marked improvement in the clarity of the modern high resolution ultrasound scanners, combined with the increased expertise of their veterinary operators, has led to a much earlier and more accurate diagnosis of twin conceptuses. Consequently, a significant proportion of unicornuate twins are diagnosed nowadays which, prior to the application of the scanner to Thoroughbred breeding in Britain in 1981 (Simpson et al, 1982), were either not diagnosed or not treated and thus would have resulted in the death and resorption of one or both conceptuses between days 17 and 35 after ovulation (Table 4). The increased incidence of twins nowadays may also be the result of better veterinary management of the oestrous cycle and the consequent overall improvement in fertility within the Thoroughbred mare population as a whole.

The high overall success rate of manual reduction of twin conceptuses to a viable singleton (92\%) is no doubt the underlying cause of the sharp reduction in the rate of abortion due to twinning in horses over the past 25 years, from $22 \%$ as recorded by Jeffcott and Whitwell (1973) to the current level of $<7 \%$ (A. Blunden and K. Whitwell, unpublished observations). The $10 \%$ improvement in success when crushing one 
of bicornuate, compared with unicornuate, twins may be explained both by the increased ease of manipulating either of the two conceptuses when in separate uterine horns, and the reduced risk of damaging the neighbouring conceptus. This lack of harm to the remaining conceptus was illustrated by the observation that, in the present survey, the incidence of fetal death later in gestation was no higher in the mares in which a twin conceptus was ruptured manually than in the remainder of the population carrying singleton pregnancies. The high success rate from the manual reduction of twins, combined with the similar pregnancy rates achieved in mares exhibiting single and double ovulations, emphasises the advantage to be gained from mating mares that produce multiple dominant follicles and may also have contributed to the increased end of season foaling rate.

Despite definite differences between individual stallions in pregnancy rates achieved in their groups of mares, the more dominant effects of mare age and status on per cycle pregnancy rates overshadowed these differences. Indeed, any negative effect of the stallion was somewhat compensated for by careful limitation of the number of matings so that, overall, mares were mated a mean of only 1.12 times in a single period of oestrus. However, any mares that were not diagnosed as pregnant after their first mated oestrous period were remated in subsequent oestrous cycles to the extent that, by the end of the covering season, they had been mated a mean of 1.88 times before they became pregnant.

Tab. 4: The influence of uterine distribution of the conceptuses on the success rate when treating twins by manual rupture of one conceptus per rectum.

Einfluss der intrauterinen Verteilung der Zwillingsanlagen auf die Reduktionsrate auf einen Einling nach manueller Kompression einer Anlage

\begin{tabular}{|c|c|c|c|c|c|}
\hline Treatment & $\begin{array}{l}\text { Uterine } \\
\text { distribution }\end{array}$ & $\begin{array}{l}\text { Number of } \\
\text { attempts }\end{array}$ & $\begin{array}{l}\text { Successful reduction } \\
\text { to a singleton }\end{array}$ & $\begin{array}{l}\text { Death of both } \\
\text { conceptuses }\end{array}$ & Success rate (\%) \\
\hline \multirow{3}{*}{$\begin{array}{l}\text { Manual rupture of one } \\
\text { conceptus }\end{array}$} & Bilateral & 60 & 58 & 2 & 97 \\
\hline & Unilateral & 61 & 53 & 8 & 87 \\
\hline & Uterine body & 4 & 3 & 1 & 75 \\
\hline \multirow{2}{*}{ No treatment } & Bilateral & 4 & 3 & 1 & 75 \\
\hline & Unilateral & 7 & 5 & 2 & 71 \\
\hline
\end{tabular}


Comparison of the results obtained in the two surveys conducted 15 years apart on similar populations of Thoroughbred mares shows that significant improvements have been achieved in foaling rates. These may be attributed to better management of the oestrous cycle with increased use of the ultrasound scanner to monitor follicular development, diagnose and treat uterine problems, and diagnose and successfully reduce twin conceptuses to an ongoing singleton pregnancy. Nevertheless, despite the reduction in the proportion of barren mares in the breeding population, the age and reproductive status of the mares still have marked influences on fertility within the population. Jeffcott et al. (1982) reported that the major reason for breeding losses in the Thoroughbred population at that time was failure of conception. Nowadays it appears that the persistence of a high incidence of pregnancy failure between days 15 and 35 of gestation represents the major loss to the Thoroughbred breeding industry.

\section{Acknowledgements}

We are grateful to the members of Greenwood, Ellis and partners and Rossdale and partners, veterinary practices, and to the managers and staffs of the 22 Newmarket studfarms, for access to their records and help with extraction of the relevant information. We are also grateful to Mr S.W.Ricketts for making his analysis of Weatherbys general Stud Book records available to us. We thank Katie Barrett, Catriona Glover, Mark Murrell, Gemma Richards, Louise White and Greg Williams for assistance with collection and computer entry of the data. The study was financed by The Thoroughbred Breeders' Association, The Childwick Trust and The Havemeyer Foundation.

\section{Literature}

Adams, G.P., Kastelic, J.P., Bergfelt, D.R. and Ginther, O.J. (1987): Effect of uterine inflammation and ultrasonically-detected uterine pathology on fertility in the mare. J Reprod Fert Suppl. 35, 445-454.

Ball, B.A., Little T.V., Hillman R.B. and Woods, G.L. (1986): Pregnancy rates at days 2 and 14 and estimated embryonic loss rates prior to day 14 in normal and subfertile mares. Theriogenology $26,611-$ 619.

Bracher, V., Mathias, S. and Allen, W.R. (1996): Influence of chronic degenerative endometritis (endometrosis) on placental development in the mare. Equine Vet. J. 28, 180-188.

Bristol, F. (1982): Breeding behaviour of a stallion at pasture with 20 mares in synchronised oestrus. J. Reprod. Fert. Suppl. 32, 71-77.

Bristol, F. (1987): Fertility of pasture bred mares in synchronised oestrus. J. Reprod. Fert. Suppl. 35, 39-43.

Brück, I., Anderson, G.A. and Hyland, J.H. (1993): Reproductive performance of Thoroughbred mares on six commercial stud farms. Aust. Vet. J. 70, 299-303.

Downing, J.A. and Scaramuzzi, R.J. (1991): Nutrient effects on ovulation rate, ovarian function and the secretion of gonadotrophin and metabolic hormones in sheep. J. Reprod. Fert. Suppl.. 43, 209-227.

Duane, H.K. and Buckrell, B.C. (1997): Breeding strategies. In: Current Therapy in Large Animal Theriogenology. Ed. R.S.Youngquist, W.B. Saunders and Co, Philadelphia, 603-611.

Fogarty, N.M., Hall, D. G., Dawe, S.T., Atkinson, W. and Allan, C. (1991): Management of the highly fecund ewe types and their lambs for 8 monthly lambing. 1. Effect of lamb weaning age on ewe reproductive activity in spring. Aust. J. exp. Agric. 32, 421-423.

Ginther, O.J. (1982): Twinning in mares: a review of recent studies. J Equine vet Sci 2, 127-135

Ginther, O.J. (1983): Fixation and orientation of the early equine conceptus. Theriogenology 19, 613-623.
Ginther, O.J. (1989): Twin embryos in mares I: From ovulation to fixation. Equine vet J 21, 166-170.

Held, J.P. and Rohrbach, B. (1991): Clinical significance of uterine biopsy results in the maiden and non-maiden mare. J Reprod Fert Suppl. 35, 698-699 (Abst)

Hutton, C.A. and Meacham, T.N. (1968): Reproductive efficiency on fourteen horse farms. J. Anim. Sci. 27, 434-438.

Jeffcott, L.B. and Whitwell, K.E. (1973): Twinning as a cause of fetal and neonatal loss in the Thoroughbred mare. J Comp Path 83, 91-106.

Jeffcott, L.B. , Rossdale, P.D., Freestone, J., Frank, C. and Towers-Clark, P.F. (1982):: An assessment of wastage in Thoroughbred racing from conception to 4 years of age. Equine vet. J. 14, 185-198.

Laing, J.A. and Leech, F.B. (1975): The frequency of infertility in Thoroughbred mares. J Reprod Fert Suppl. 23, 307-310.

Merkt, H., Jacobs, K.O., Klug, E. and Aukes, E. (1979): An analysis of stallion fertility rates from the breeding documents of the Landgestüt Celle over a 158-year period. J. Reprod. Fert. Suppl. 27, 73-77.

Morley, P.S. and Townsend, H.G.G. (1997): A survey of reproductive performance in Thoroughbred mares and morbidity, mortality and athletic potential of their foals. Equine vet. J. 29, 290-297.

Osborne, V.E. (1975): Factors influencing foaling percentages in Australian mares. J. Reprod. Fert. Suppl.. 23, 477-483.

Pycock, J.F. and Newcombe, J.R. (1996): Assessment of the effect of three treatments to remove intrauterine fluid on the pregnancy rate in mares. Vet. Rec. 138, 320-323.

Ricketts, S.W. and Alonso, S. (1991): The effect of age and parity on the development of equine chronic endometrial disease. Equine vet. J. 23, 189-192.

Ricketts, S.W. and A. Barrelet (2001): The ability of mares to respond to treatment for uterine abnormalities diagnosed by endometrial biopsy and some causes for failure to respond. A review of 1099 cases. Pferdeheilkunde 17,

Sanderson, M.W. and Allen, W.R. (1987): Reproductive efficiency of Thoroughbred mares in the United Kingdom. In: Proc. $9^{\text {th }}$ Bain Fallon Memorial Lectures, Ed. T. Huntington, AEVA, Sydney, 31-41,

Simpson, D.J., Greenwood, R.E.S., Ricketts, S.W., Rossdale, P.D., Sanderson, M.W. and Allen, W.R. (1982): Use of ultrasound echography for early diagnosis of single and twin pregnancy in the mare. $J$ Reprod Fert Suppl. 32, 431-439.

Sullivan, J.J. and Pickett, B.W. (1975): Influence of ejaculation frequency of stallions on characteristics of semen and output of spermatozoa. J. Reprod. Fert. Suppl. 23, 29-34.

Sullivan, J.J., Turner, P.C., Self, L.C., Gutteridge, H.B. and Bartlett, D.E. (1975): Survey of reproductive efficiency in the Quarterhorse and Thoroughbred. J. Reprod. Fert. Suppl . 23, 315-318.

von Lepel, J. (1975): Control of fertility in Thoroughbred horses in West Germany. J. Reprod. Fert. Suppl. 23, 311-313.

Waelchli, R.O. (1990): Endometrial biopsy in mares under non-uniform breeding management conditions: Prognostic value and relationship with age. Can vet J 31, 379-384.

Wathes, D.C. (1992): Embryonic mortality and the uterine environment. J. Endocr. 134, 321-325.

Woods, G.L., Baker, C.B., Baldwin, J.L., Ball, B.A., Bilinksi, J., Cooper, W.L., Ley, W.B, Mark, E.C. and Erl, H.N. (1987): Early pregnancy loss in broodmares. J Reprod Fert Suppl. 35, 455-459.

Lee H.A. Morris and W.R. Allen

Thoroughbred Breeders' Association Equine Fertility Unit

Mertoun Paddocks

Woodditton Road

Newmarket

Suffolk CB8 9BH

U.K.

Tel.: (01638) 662491

Fax: (01638) 667207 